\title{
SEJARAH MASYARAKAT NELAYAN SUKU BUGIS DI DESA POLEWALI, KECAMATAN LAINEA KABUPATEN KONAWE SELATAN (1950-2017) ${ }^{1}$ \\ HISTORY OF THE FISHERMEN FISHERMAN BUGIS TRANSPORT IN POLEWALI VILLAGE, LAINEA SUB-DISTRICT, KONAWE SELATAN DISTRICT (1950-2017)
}

\author{
Ibrahim $^{2}$ \\ Email:psj.ibrahim@gmail.com \\ Dade Prat Untarti ${ }^{3}$ \\ email: dade.pratuntarti@uho.ac.id
}

${ }^{1)}$ Hasil Penelitian Tahun 2019, ${ }^{2)}$ Alumni Jurusan Pendidikan Sejarah, ${ }^{3)}$ Dosen UHO

\begin{abstract}
ABSTRAK: Permasalahan utama dalam penelitian ini adalah: (1) Bagaimana sejarah kedatangan orang Bugis di Desa Polewali Kecamatan Lainea Kabupaten Konawe Selatan? (2) Bagaimana kondisi sosial ekonomi dan budaya masyarakat nelayan suku Bugis di Desa Polewali Kecamatan Lainea Kabupaten Konawe Selatan (1950-2017)? Metode yang digunakan dalam penelitian ini adalah metode penelitian sejarah yang dikemukakan oleh Helius Syamsuddin bahwa tata kerja penelitian sejarah terdiri dari tiga tahapan yaitu: (1) Pengumpulan Data (Heuristik) (2) Kritik Sumber (Verifikasi) (3) Penulisan Sejarah (Historiografi). Hasil penelitian ini menunjukkan bahwa: (1) Awal kedatangan orang Bugis di Desa Polewali untuk mengamankan diri karena pada saat itu mereka dikira mata-mata dari tentara Jepang jadi mereka meninggalkan daerah asal mereka yaitu Bone Sulawesi Selatan dan kemudian mereka menuju di Desa Polewali. Hal yang mendorong mereka tinggal di Polewali karena kondisi laut yang bagus. Pada tahun 1950 pertama sekali orang Bugis berlabuh di Desa Polewali Nama Desa Polewali berasal dari bahasa Bugis yang terdiri dari kata "pole" dan "wali", pole artinya datang dan wali artinya empat penjuru, polewali berarti datang dari empat penjuru. Orang Bugis banyak yang menjadi nelayan di Desa Polewali karena Desa Polewali berada di pinggir laut dan mempunyai potensi laut yang bisa menunjang pendapatan nelayan. (2) Kondisi kehidupan masyarakat Desa Polewali sejak tahun 1950-2017 dapat dilihat dari; (a) Kondisi sosial dalam masyarakat yang dapat dilihat dari interaksi sosialnya. Interaksi sosial yang dimaksud dalam penelitian ini adalah hubungan sosial antara sesama masyarakat nelayan suku Bugis dengan orang lain, baik menyangkut hubungan kerjasama dan persaingan. Dalam menangkap ikan dan memasarkan hasil tangkapan. (b) Kondisi ekonomi masyarakat nelayan suku Bugis di Desa Polewali (c) Kondisi budaya merupakan salah satu bagian terpenting dalam kehidupan masyarakat nelayan yang digunakan sebagai tata aturan yang mengatur pola perilaku setiap anggotaanggota dalam kehidupan masyarakat Desa Polewali
\end{abstract}

Kata Kunci: Sejarah, Kondisi Sosial Ekonomi

ABSTRACT: The main problems in this study are: (1) What is the history of the arrival of the Bugis in the Polewali Village of Lainea Subdistrict, Konawe Selatan District? (2) What are the socio-economic and cultural conditions of the Bugis fishing community in Polewali Village, Lainea Subdistrict, Konawe Selatan Regency (1950-2017)? The method used in this study is the historical research method proposed by Helius Syamsuddin that the work of historical research consists of three stages, namely: (1) Data Collection (Heuristics) (2) Source Criticism (Verification) (3) Historical Writing (Historiography). The results of this study indicate that: (1) The initial arrival of the Bugis in the Polewali Village to secure themselves because at that time they were thought to be spies from the Japanese army so they left their home region of Bone South Sulawesi and then they headed to Polewali Village. The thing that pushed them to stay in Polewali was because of the good sea conditions. In 1950 the Bugis first anchored in the Polewali Village The name Polewali Village came from the Bugis language which consisted of the words "pole" and "guardian", pole meant to come and guardian meant four directions, polewali meant to come from four directions. Many Bugis people become fishermen in Polewali Village because Polewali Village is located on the seafront and has sea potential that can support the income of fishermen. (2) The living conditions of the people of Polewali Village since 1950-2017 can be seen from; (a) Social conditions in society which can be seen from social interactions. The social interaction referred to in this study is the social relationship between fellow Bugis fishing communities with other people, both concerning the relationship of cooperation and competition. In catching fish and marketing the catch. (b) Economic conditions of the Bugis fishing community in Polewali Village (c) Cultural conditions are one of the most important parts of the fishing community's life which are used as rules governing the behavior patterns of each member in the Polewali Village community life.

Keywords: History, Socio-Economic Conditions 


\section{PENDAHULUAN}

Mempelajari suatu peristiwa sejarah yang terjadi pada suatu bangsa atau suatu daerah adalah sangat penting, karena dari peristiwa tersebut dapat dipetik pelajaran untuk dijadikan suatu pedoman dalam memilih dan menganalisa peristiwa-peristiwa yang terjadi pada masa sekarang, sehingga pada akhirnya dapat disusun langkah dan tindakan pada masa yang akan datang.

Sejarah yang dijelaskan oleh parah ahli secara absolut mengungkapkan bagaimana pola gerak sejarah yang terjadi dari masa lalu, dan secara umum memiliki pola siklus, dan spiral. Dari teori-teori tersebut mengungkapkan bagai mana proses perubahan kehidupan manusia dalam objek kajian sejarah yang dimulai pada tingkat awal, pertengahan, keemasaan dan akhir dari peradaban tersebut yang kemudian ini menurut para ahli menjadi pola dan konsep teori gerak sejarah.

Gerak sejarah merupakan alur yang menggambarkan bagaimana proses jalannya sejarah yakni berupa suatu pola kejadian dalam berbagai peristiwa kehidupan manusia. Terdapat dua pandangan berkenaan dengan sifat gerak sejarah (Muhammad Arif, 2011: 92). Pertama pandangan yang menyatakan bahwa peristiwa sejarah merupakan suatu kejadian yang berulang-ulang.

Aliran gerak sejarah perkembangan atau progresif linear berusaha menggambarkan suatu peristiwa sejarah menjadi lebih bemakna. Hal ini karena setiap peristiwa sejarah memang berkaitan erat dengan waktu dan ruang tertentu. Peristiwa sejarah menggambarkan adanya proses panjang perjuangan manusia untuk meningkatkan kualitas kehidupannya. Pandangan ini dianggap juga lebih ilmiah karena tidak lagi menilai suatu peristiwa sejarah sesuatu yang bersifat komunis (semua yang ada dijagat raya) yang terlepas dari konteks waktu dan ruang tempat suatu peristiwa terjadi (Muhamad Arif, 2011 : 95).

Menurut Hasan Shadily (1992:47) menyatakan bahwa mayarakat merupakan golongan besar atau kecil yang terdiri dari beberapa manusia, atau karena sedirinya bertalian secara golongan dan pengaruh-mempengaruhi satu sama lain. Ada empat kriteria yang perlu dipenuhi agar suatu kelompok dapat disebut masyarakat, yaitu : (1) Kemampuan bertahan melebihi masa hidup seorang individu; (2) Rekrutmen seluruh atau sebahagian anggota melalui reproduksi; (3) Kesetiaan pada suatu "sistem tindakan utama "; (4) Adanya sistem tindakan utama yang bersifat "swasembada". Inkeles mengemukakan bahwa suatu kelompok hanya dapat kita namakan masyarakat bila kelompok tersebut dapat bertahan stabil untuk beberapa generasi walaupun sama sekali tidak ada orang atau kelompok lain diluar kelompok tersebut (Sunarto, 2004 : 54).

Masyarakat nelayan ialah kumpulan manusia yang hidup bersama di suatu tempat dengan aturan dan cara tertentu. Individu, keluarga dan kumpulan-kumpulan kecil merupakan anggota sebuah masyarakat. Jaringat erat wujud dalam kalangan anggota tersebut, khususnya melalui hubungan bersemuka. Daripada pergaulan ini, terbina pola hubungan sosial yang berulang sifatnya seperti kegiatan gotong royong, bersama-sama merayakan sesuatu perayaan melalui rumah terbuka, berkumpul menyambut pembesar yang datang berkunjung dan membantu mereka yang ditimpa malapetaka atau menziarahi jiran yang sakit tenat atau yang telah meninggal dunia. Kekerapan pergaulan ini membina satu kesepaduan dalam masyarakat tersebut sebagai suatu unit sosial. Dalam konteks Malaysia, hubungan harmonis antara berbagi kumpulan etnik dapat membina sebuah masyarakat Malaysia yang teguh, (Mulyadi, 2005: 128)

Menurut Satria (2002: 12). Nelayan sering didefinisikan sebagai orang yang melakukan kegiatan penangkapan ikan di laut. Dilihat dari status penguasaan kapitalnya, nelayan dapat dibedakan menjadi nelayan pemilik dan nelayan buruh. Nelayan pemilik atau juragan adalah orang yang memiliki sarana penangkapan, seperti kapal perahu, jaring dan alat tangkap lainnya. Sementara nelayan buruh adalah orang yang menjual jasa tenaga kerja sebagai buruh dalam kegiatan penangkapan ikan di laut atau sekarang lebih dikenal anak buah kapal (ABK). Mengenai pengertiannya, menurut Ditjen Perikanan diacu dalam Satria (2002: 14) mendefinisikan nelayan sebagai orang yang secara aktif melakukan pekerjaan dalam operasi penangkapan ikan binatang air lainnya tanaman air. Adapun orang yang hanya melakukan pekerjaan seperti membuat jaring atau mengangkut alat-alat perlengkapan ke dalam perahu kapal tidak dikategorikan sebagai nelayan. Sedangkan ahli mesin dan juru masak yang bekerja di atas kapal penangkapan walaupun mereka tidak secara langsung melakukan penangkapan ikan, dapat disebut sebagai nelayan. 
Seperti halnya yang dikemukakan soleh Sartono Kartodirjo (1990: 11) bahwa ilmu sejarah juga mengajarkan kepada kita (manusia) bahwa hari depan tiap bangsa tidak berkembang dalam suatu kevakuman semata melainkan berkembang dari realitas atau keadaan sekarang, berkaitan dengan hari kemarin. Dengan demikian maka perkembangan dapat diartikan sebagai suatu proses perjalanan dalam priode waktu yang disertai dengan usaha-usaha perluasaan atau mencapai kemajuan.

Perubahan dalam masyarakat dapat mengenai nilai-nilai sosial, pola-pola perilaku, organisasi sosial, dan lain sebagainya. Menurut pandangan yang disampaikan oleh Max Weber bahwa perubahan sosial merupakan kosep dasar yang menyusun pembagian suatu struktur sosial menjadi beberapa bagian atau lapisan yang berkait. Konsep ini memberikan gambaran bahwadalam suatu struktur sosial ada ketidak samaan posisi sosial antara individu didalamnya. Terdapat tiga dimensi di mana suatu msyarakat terbagi dalam suatu susunan atau stirtifikasi, status kekuasaan. Jadi perubahan social dapatlah didefinisikan sebagai suatu peristiwa yang menyangkut perubahan posisi unsur-unsur dalam suatu sistem sosial (Nasution, 1998: 157).

Suku Bugis merupakan salah satu kelompok suku bangsa/etnik yang ada di Indonesia dengan wilayah asal Sulawesi Selatan. Penyebaran Suku Bugis di seluruh Tanah Air disebabkan mata pencaharian orang-orang Bugis pada umumnya adalah nelayan dan pedagang. Hal lain juga disebabkan adanya faktor historis orang-orang Bugis itu sendiri di masa lalu yaitu semenjak kalahnya Kerajaan Gowa dalam berperang melawan Belanda yang di akhiri dengan Perjanjian Bongaya pada tahun 1667 yang terasa sangat mengikat dan menghina kaum Bugis-Makassar.

Hal ini menyebabkan banyaknya orang Bugis bermigrasi terutama di daerah pesisir. Selain itu budaya merantau juga didorong oleh keinginan akan kemerdekaan. Kebahagiaan dalam tradisi Bugis hanya dapat diraih melalui kemerdekaan. Keberadaan orang Bugis sangat mudah ditemukan, terutama di wilayah Sulawesi Tenggara. Hal ini juga terlihat di Desa Polewali yang mayoritas masyarakatnya adalah Suku Bugis

Desa Polewali adalah salah satu desa yang berada di Kecamatan Lainea Kabupaten Konawe Selatan yang memiliki letak geografis berada di pesisir pantai. Meskipun disadari bahwa tidak semua desa-desa di kawasan pesisir memiliki penduduk yang bermata pencaharian sebagai nelayan tetapi di wilayah ini, sebagian besar masyarakatnya hidup dari mengelola sumber daya pesisir dan laut, baik secara langsung maupun tidak langsung.

Masyarakat nelayan Suku Bugis Desa Polewali merupakan masyarakat yang hidup, tumbuh, dan berkembang di kawasan pesisir. Bagi masyarakat nelayan Suku Bugis Desa Polewali, laut bukan hanya merupakan hamparan air yang membatasi wilayah daratan, tapi lebih dari itu yaitu sebagai sumber pemenuhan kebutuhan sehari-hari.

\section{METODE PENELITIAN}

Penelitian ini dilaksanakan di Desa Polewali Kecamatan Lainea Kabupaten Konawe Selatan, dengan penelitian sejarah yang bersifat deskriptif kualitatif yakni penelitian memberikan gambaran yang jelas tentang latar belakang sejarah kedatangan orang Bugis di Desa Polewali, Kecamatan Lainea Kabupaten Konawe Selatan, serta kondisi sosial ekonomi dan budaya masyarakat nelayan suku Bugis di Desa Polewali Kecamatan Lainea Kabupaten Konawe Selatan. Sumber data yang digunakan dalam penelitian ini, terdiri atas tiga kategori, yaitu sumber tertulis, sumber lisan dan sumber benda. Prosedur penelitian yang digunakan dalam penelitian ini adalah mengacu pada metode penelitian sejarah yang dikemukakan oleh Helius Syamsuddin (2007:85239) bahwa tata kerja penelitian sejarah terdiri tiga (3) tahapan yaitu; 1) heuristik terdiri dari pengamatan, wawancara dan sutudi dokumen, 2) kritik yang terdiri dari kritik ekstern dan krtik intern, 3) historiografi, interprestasi (penafsiran), penjelasan (eksplanasi), ekspose (penyajian). 


\section{HASIL PENELITIAN DAN PEMBAHASAN}

\section{Sejarah Kedatangan Orang Bugis di Desa Polewali Kecamatan Lainea Kabupaten Konawe Selatan.}

Desa Polewali merupakan desa yang berada di pesisir laut Sulawesi Tenggara. Nama Desa Polewali berasal dari bahasa Bugis yaitu kata Pole dan wali. Pole artinya datang dari dan wali yang artinya empat penjuru. Polewali berarti datang dari empat penjuru, karena pada saat itu di Desa Polewali banyak terdapat mata air untuk kebutuhan manusia. Desa Polewali terbentuk pada tahun 1955 sebelum terbentuk sebagai desa, Desa Polewali hanyalah sebuah tempat persinggahan orangorang Bugis yang berlayar dari Bone Sulawesi Selatan ke Kendari Sulawesi Tenggara yaitu diawali oleh Cabang dan teman-teman yang mampir berlabuh didaratan Polewali karena kondisi alam yang mendukung akhirnya sebagian orang memilih Desa Polewali untuk menetap dan bermukim diwilayah ini. Sebagian Orang Bugis yang lain tinggal di Desa Polewali itu untuk mengamankan diri karena pada saat itu mereka dikira mata-mata dari tentara Jepang jadi mereka meninggalkan daerah asal mereka yaitu Bone Sulawesi Selatan dan kemudian mereka menuju di Desa Polewali, hal yang mendorong mereka tinggal di Polewali karena kondisi lautnya. (Usman, wawancara, 8 Juni 2018).

Masyarakat suku Bugis di Desa Polewali berasal dari beberapa wilayah di Sulawesi Selatan yaitu ada yang berasal dari Bone, Sinjai, Sengkang dan beberapa wilayah lain sekitarnya. Pola perpindahan (mobilitas) penduduk dibedakan menjadi empat macam sebagai berikut: (1) Pola perpindahan harian yaitu perpindahan penduduk setiap hari dari desa ke kota untuk mencari makan. Setiap hari melakukan perjalanan pergi pulang (pergi pada pagi hari dan pulang pada sore hari). (2) Pola perpindahan musiman, yaitu perpindahan tempat tinggal penduduk yang dilakukan pada musim-musim tertentu. Contoh: perpindahan penduduk dari kaki pegunungan Himalaya, bila musim dingin turun ke daerah lembah, sedangkan saat musim panas mereka akan kembali ke daerah semula. (3) Pola perpindahan menetap, yaitu perpindahan penduduk dari satu tempat ke tempat lain dengan tujuan menetap sekurang-kurangnya enam bulan lamanya.

1. Pola perpindahan tidak menetap, yaitu perpindahan penduduk dalam jangkah waktu pendek, tidak begitu teratur waktunya, dan hanya berdasarkan waktunya, dan hanya berdasarkan kebutuhan, Contoh : pedagang keliling yang melakukan promosi produk dari suatu perusahaan.

Dari pola perpindahan di atas, maka pola perpindahan yang dilakukan orang Bugis di Desa Polewali Kecamatan Lainea adalah pola perpindahan menetap. Hal tersebut disebabkan oleh beberapa faktor antara lain: (a) Keadaan lingkungan; Desa Polewali adalah desa yang berada di pesisir pantai sehingga penduduk di desa tersebut dominan bermata pencaharian sebagai nelayan. (b) Tingkat pendidikan yang rendah; Pendidikan merupakan salah satu faktor yang mempengaruhi berkembangnya sebuah kawasan, dimana masyarakat akan berfikir lebih kreatif dalam mengembangkan pengetahuan yang mereka miliki. Dari hasil data yang ada menunjukan bahwa pendidikan masyarakat Desa Polewali masih kurang dari kata cukup, hal ini terbukti dengan jumlah penduduk yang masih sangat minim untuk melanjutkan pendidikannya ke jenjang yang lebih tinggi. Pekerjaan yang turun temurun di wariskan dari para orang tua mereka menjadi faktor terbentuknya pemikiran para generasi muda bahwa tanpa mengeyam pendidikan pun mereka sudahh memiliki mata pencaharian yang telah diwariskan oleh orang tuanya. (c) Terbatasnya lapangan kerja; Tak dapat dipungkiri bahwa kurangnya lapangan pekerjaan membuat masyarakat merasa enggan untuk berusaha mendapatkan pekerjaan yang berbeda dari pada umumnya. Sebagian kecil masyarakat Desa Polewali memilih mencari kerja di luar kampung dan sebagian yang lain lebih memilih menjadi nelayan. 
Kondisi Sosial, Ekonomi, dan Budaya Masyarakat Nelayan Suku Bugis di Desa Polewali Kecamatan Lainea Kabupaten Konawe Selatan

\section{Kondisi Sosial}

Kondisi sosial dalam masyarakat dapat dilihat dari interaksi sosialnya. Interaksi sosial yang dimaksud dalam penelitian ini adalah hubungan sosial antara sesama masyarakat nelayan suku Bugis dengan orang lain, baik menyangkut hubungan kerjasama dan persaingan. Dalam menangkap ikan dan memasarkan hasil tangkapan.

Sektor ekonomi sangat membentuk karakteristik masyarakat nelayan dalam kehidupan masyarakat akan mempengaruhi pola interaksi yang ada. Interaksi sosial dalam kenyataan mempunyai wujud dalam kehidupan masyarakat baik masyarakat pendatang kelompok mayoritas maupun penduduk asli yang termasuk kelompok dominan di tempat itu. Sehubungan dengan hal itu menurut Soerjono Soekanto (1987: 52) berlangsungnya suatu proses interaksi didasarkan pada berbagai faktor yaitu: (a) Faktor imitasi yaitu faktor yang dapat mendorong untuk mengetahui kaidah-kaidah yang berlaku. (b) Faktor identifikasi yaitu faktor yang sering terjadi dan sangat berperan dalam interaksi sosial, dimana identifikasi merupakan kecenderungan atau keinginan dalam diri seseorang untuk menjadi sama orang lain. (c) Faktor simpati yaitu perasaan tertarik orang yang satu terhadap yang lain yang lebih mempengaruhi oleh keinginan untuk saling bersama, saling bersahabat atau mencintai.

Dalam membicarakan tentang masalah sosial tidak dapat di lepaskan dari hubungan kemasyarakatan atau penyesuaian diri di antara penduduk, baik terhadap sesama suku Bugis maupun masyarakat luas lainnya. Sosialisasi nelayan suku Bugis di Desa Polewali dapat dilihat pada hubungan kemasyarakatan mereka baik sesama masyarakat suku Bugis maupun masyarakat lainnya. Hubungan kemasyarakatan di antara penduduk sangat baik dan harmonis. Mereka saling membantu dan menjaga satu sama lain. Dalam melakukan kegiatan-kegiatan yang bersifat umum, mereka sangat aktif dan selalu berpartisipasi dalam kegiatan-kegiatan yang dilakukan secara gotong royong oleh masyarakat banyak, seperti kerja bakti, memperbaiki jalan, membersihkan masjid, membersihkan lingkungan dan memberikan sumbangan untuk sesuatu kegiatan dalam masyarakat. Dalam kegiatan yang bersifat pribadi, mereka juga saling membantu dan tolong menolong seperti halnya ada kegiatan atau mengadakan hajatan seperti pesta perkawinan.

Pelaksanaan pesta perkawinan biasanya meminta saran dan pendapat pada masyarakat lainnya atau para ketua adat. Pelaksanaan pesta perkawinan tersebut maka terlihat kesibukankesibukan penduduk guna membantu mempersiapkan yang dibutuhkan oleh tuan rumah. Seperti para orang tua membantu memberikan sumbangan yang dibutuhkan oleh tuan rumah. Para anakanak muda membantu dalam pendirian tenda dan melengkapi perlengkapan yang dibutuhkan dalam pelangsungan acara tersebut. perlengkapan yang ada seperti piring, gelas, dan alat masak lainnya biasanya meminjam kepada tetangga tanpa harus menyeka karena kerabat paling dekat adalah tetangga.

Tingginya sosialisasi masyarakat Suku Bugis di Desa Polewali dapat dilihat dari rendahnya interaksi negatif yang terjadi di antara penduduk Suku Bugis dengan adanya sosialisasi tersebut hubungan dalam perkembangan sekarang, orang tua tidak lagi mengatur segalanya tetapi anakanak mereka sudah mempunyai hak untuk menentukan pilihan tetapi juga tidak terlepas dari pandangan dan pengawasan serta saran dari orang tua.

\section{Kondisi Ekonomi}

Proses perkembangan ekonomi masyarakat nelayan Suku Bugis di Desa Polewali yaitu mempunyai peran yang sangat substansial dalam perkembangan perekonomian masyarakat Desa Polewali pada tahun 1950-2017 mengingat desa ini mayoritas masyarakatnya berpropesi sebagai nelayan.

Pertumbuhan ekonomi adalah proses perubahan kondisi perekonomian suatu negara secara berkesinambungan menuju keadaan yang lebih baik selama periode tertentu. Pertumbuhan ekonomi dapat diartikan juga sebagai proses kenaikan kapasitas produksi suatu perekonomian yang 
diwujudkan dalam bentuk kenaikan pendapatan nasional. Adanya pertumbuhan ekonomi merupakan indikasi keberhasilan pembangunan ekonomi.

Perkembangan ekonomi tak lepas dari pertumbuhan ekonomi, perkembangan ekonomi mendorong pertumbuhan ekonomi, dan sebaliknya, pertumbuhan ekonomi memperlancar proses perkembangan ekonomi. Proses kenaikan kapasitas produksi suatu perekonomian yang diwujudkan dalam bentuk kenaikan pendapatan. Suatu wilayah dikatakan mengalami pertumbuhan ekonomi apa bila terjadi peningkatan yang rill. Adanya perkembangan ekonomi merupakan indikasi keberhasilan perkembangan ekonomi masyarakat khususnya masyarakat nelayan.

Kehidupan masyarakat nelayan Suku Bugis di Desa Polewali sejak pertama kali mereka mulai melaut masih secara tradisional baik dalam proses penangkapan ikan maupun perahu yang mereka pakai yaitu masih menggunakan tenaga manusia dengan cara mendayung perahu tersebut karena pada saat itu belum ada yang menggunakan mesin. Selain itu alat yang digunakan masih sangat sederhana, seperti jaring yang terbuat dari nilon atau tasi, dimana besar kecilnya tergantung para penangkap ikan dan alat pancing yang diberi penggulung atau pegangan. Kedua alat tersebut digunakan pada malam hari dan siang hari, disaat mereka mencari ikan di malam hari masih menggunakan lampu petromaks. Seiring perkembangan jaman, hampir semua sudahh mulai menggunakan mesin. Untuk membedakan perkembangan perekonomian masyarakat nelayan Suku Bugis di Desa Polewali dapat dilihat pada tabel berikut:

Tabel . Perkembangan Perekonomian Masyarakat Nelayan Suku Bugis Berdasarkan Periode di Desa Polewali

\begin{tabular}{|c|c|c|}
\hline Periode & $\begin{array}{c}\text { Perkembangan } \\
\text { Perekonomian } \\
\end{array}$ & Kisaran penghasilan \\
\hline $\begin{array}{l}\text { Awal Kedatangan } \\
(1950-1980)\end{array}$ & $\begin{array}{l}\text { - Masih menggunakan sistem } \\
\text { barter } \\
\text { - Alat yang digunakan untuk } \\
\text { menangkap ikan masih } \\
\text { sederhana berupa pancing } \\
\text { dan jaring } \\
\text { - Perahu yang digunakan } \\
\text { untuk menangkap ikan } \\
\text { belum menggunakan mesin }\end{array}$ & $\begin{array}{l}\text { - Tidak terprediksi } \\
\text { karena masih } \\
\text { menggunakan } \\
\text { sistim barter. }\end{array}$ \\
\hline Perkembangan (1980-2000) & $\begin{array}{l}\text { - Telah mengenal sistem } \\
\text { perdagangan. } \\
\text { - Perahu yang digunakan } \\
\text { telah menggunakan mesin. } \\
\text { - Telah dibangun perlelangan } \\
\text { ikan kecil sebagai sarana } \\
\text { penjualan hasil laut. }\end{array}$ & $\begin{array}{l}\text { - Penghasilan } \\
\text { nelayan } \\
\text { berkisaran 70-700 } \\
\text { perbulan }\end{array}$ \\
\hline Saat ini (2000-2017) & $\begin{array}{l}\text { - Penangkapan ikan memiliki } \\
\text { kemajuan yaitu membuat } \\
\text { beberapa keramba dan } \\
\text { menggunakan mesin tees. } \\
\text { - Beberapa masyarakat Bugis } \\
\text { berprofesi ganda yaitu } \\
\text { sebagai pedagang dan } \\
\text { nelayan. } \\
\text { - Taraf hidup meningkat } \\
\text { sehingga berdampak pada } \\
\text { pendidikan dan politik. }\end{array}$ & $\begin{array}{l}\text { - Penghasilan } \\
\text { nelayan } 700-1.500 \\
\text { perbulan }\end{array}$ \\
\hline
\end{tabular}

Sumber: Diolah dari Hasil Penelitian 
Seperti yang dikemukakan di atas bahwa mata pencaharian Orang Bugis adalah sebagai nelayan dan pekerjaan sampingan seperti tukang kayu dan berkebun. Dalam menunjang ekonomi keluarga dalam masyarakat Bugis di Desa Polewali kaum lak-laki sangatlah berperan dimana lakilaki mempunyai tanggung jawab penuh terhadap keluarga dalam memenuhi segala kebutuhan rumah tangga. Wanita pun dalam keluarga tidak dapat diabaikan begitu saja dalam menentukan roda kehidupan keluarga. Sebagai contoh istri nelayan, setelah suami atau kaum laki-laki pulang dari laut mencari nafkah, selanjutnya diambil alih oleh kaum wanita di mana semua hasil yang diperoleh kaum laki-laki (suami) tadi mereka olah dan di kerjakan hingga pada tahap pemasaran.

Berbicara mengenai keadaan ekonomi orang-orang Bugis yang berada di Desa Polewali dapat dikatakan bahwa ekonomi mereka sudahh mulai cukup mapan dan mempunyai keahlian dalam menangkap ikan karena pada dasarnya mereka sudahh bergantung pada kehidupan laut. Hal ini dapat dilihat pada penduduk masyarakat yaitu sebagian rumah yang beratap seng dengan dinding papan yang rapih dan dilengkapi peralatan rumah tangga yang menunjang. Sebagian ada pula rumah permanen.

a. Kondisi Pemukiman

Dalam setiap perkembangan ekonomi tentunya akan selalu memberi dampak positif pada sebuah perubahan. Perubahan tersebut dapat ditunjukkan melalui kehidupan sosial ekonomi diantaranya yaitu perubahan pola hidup. Keadaan ekonomi orang-orang Bugis yang berada di Desa Polewali dapat dikatakan bahwa ekonomi mereka sudahh diatas garis kemiskinan. Hal ini dapat dilihat pada penduduk masyarakat yaitu sebagian rumah yang beratap seng dengan dinding papan yang rapi dan dilengkapi peralatan rumah tangga yang menunjang. Selain itu dapat dilihat dari keberadaan beberapa rumah permanen milik orang Bugis yang ada di Desa Polewali. Perubahanperubahan tersebut tentunya mengarah pada sebuah perubahan pemukiman.

Berbicara tentang pemukiman, pada umumnya pola pemukiman masyarakat nelayan Suku Bugis yang berada di Desa Polewali adalah dengan membuat rumah di tepi pantai yang berdindingkan papan dan beratap rumbia. Hal ini sengaja dilakukan oleh mereka karena memudahkan untuk melakukan aktivitas di laut. Namum seiring perkembangan teknologi dan pengetahuan yang didukung dengan perkembangan perekonomian sehingga terjadi perubahan kecil pada beberapa kelompok masyarakat Bugis yang ada di Desa Polewali khususnya pada tempat tinggal atau tempat bermukim. Perubahan pemukiman itu ditunjukkan dengan keberadaan beberapa rumah permanen milik Orang Bugis di Desa Polewali. Dalam perkembangan selanjutnya pembenahan terhadap sarana dan prasarana sosial keagamaan semakin ditingkatkan utamanya mesjid sebagai pusat peribadatan mulai dibenahi, yang tadinya masih bersifat darurat diganti menjadi permanen.

b. Kondisi Pendidikan

Ada beberapa hal yang dapat menunjang lancarnya sebuah pendidikan dan yang paling berpengaruh perkembangan ekonomi pada masyarakat yang melaksanakan pendidikan. Pendidikan dapat dikatakan sangat penting karena dapat melahirkan sumber daya manusia yang berkualitas yang tentunya akan berpengaruh kepada perkembangan kehidupan sosial lainnya yang saling berkaitan.

Pendidikan adalah salah satu indikator penting dalam kehidupan berwarga terutama menyangkut pencapaian hasil-hasil pembangunan, khususnya untuk menghapus tingkat keterbelakangan warga. Hal ini disebabkan karena tingkat kemajuan pendidikan warga sangat membawa manfaat besar terhadap perubahan dan meningkatkan cakrawala berpikir dari setiap golongan tertentu. Berkaitan dengan hal ini maka perlu dikembangkan dan dibina dengan baik sehingga pada gilirannya akan dapat memberikan sumbangan yang berharga bagi pembangunan bangsa pada umumnya dan masyarakat Desa Polewali pada umumnya.

Bertolak pada uraian di atas, maka bila kita lihat latar belakang pendatang Orang Bugis di Desa Polewali pada awal kedatangan mereka, mereka menunjukkan bahwa tingkat pendidikan warga masih sangat rendah. Hal ini disebabkan oleh sejak dari daerah asalnya kesadaran akan pentingnya pendidikan sangat rendah, sehingga tidak mengherankan anak-anak mereka di batasi untk melanjutkan pendidikan ke tingkat yang lebih tinggi. Akibatnya anak-anak yang seharusnya 
sudah memasuki usia sekolah tidak tidak dapat mengikuti pendidikan pada sekolah-sekolah formal. Kalaupun anak-anak mereka yang ingin disekolahkan ( terutama sekolah menengah pertama (SMP) dan sekolah menengah atas (SMA), mereka harus pergi sekolah didesa lain dan mereka rela tinggal dirumah keluarganya atau ditempat orang lain yang berada dekat dengan sekolah. Keadaan menyebabkan banyak anak - anak yang enggan melanjutkan pendidikan dengan demikian, anakanak yang bersekolah pada kuran waktu itu jumlahnya sangat sedikit dan mayoritas hanya berpendidikan sekolah dasar (SD), setelah itu mereka bekerja membatu orang tua melaut.

Dalam perkembangan selanjutnya, sering dengan lajunya perkembangan ilmu pengetahuan dan teknologi serta lajunya kegiatan pembangunan yang dikembangkan oleh berbagai aspek kehidupan, sebelum tahun 1958 sudahh mulai dibangun satu unit sekolah dasar dengan tenaga guru yang masi terbatas. Dengan adanya lembaga sekolah formal, mulai timbul keinginan anak-anak utuk masuk sekolah. Bila di bandingkan dengan tingkat pendidikan yang sekarang sangat jauh berbeda karena pada saat itu fasilitas belajar sangat kurang perlengkapan yang dipakai sangatlah sederhana. Alat tulis menulis yang digunakan terbuat dari lempengan batu sebagai tempat menulis dan sebatang kapur tulis sebagai alat tulis. Zaman dulu pola pikir dan daya ingat mereka sangat kuat karena mereka belum mengenal yang namanya buku tulis dan buku pket yang di gunakan seperti sekarang.

Sehubungan dengan di atas, perkembangan ekonomi memang sangat berpengaruh pada beberapa hal diantaranya pendidikan. Periode-periode sebelumnya kesadaran akan pentingnya sebuah pendidikan bagi masyarakat Bugis di Desa Polewali masih sangat kurang hal ini disebabkan karena mereka merasa bahwa kehidupan mereka hanya untuk di laut yaitu menangkap ikan. Mereka berpendapat bahwa mendidik anak dengan pengalaman melaut lebih penting dan berguna dibandingkan dengan menghabis-habiskan waktu untuk belajar di sekolah. akan tetapi sering berkembangnya pengetahuan dan teknologi serta dorongan pemerintah kesadaran akan pentingnya pendidikan mulai timbul. Hal ini didukung pula pada pendapatan keluarga. Akibat dari beberapa kelancaran beberapa sumber pendapatan seperti menjadi nelayan dan pekerjaan sampingan seperti tukang kayu dan mengambil pasir di laut sehingga dapat memberi sebuah tunjangan pada pendidikan.

Sehubungan dengan penjelasan diatas, dalam menunjang ekonomi keluarga dalam masyarakat Bugis di Desa Polewali kaum laki-laki sangatlah berperang dimana laki-laki mempunyai tanggung jawab penuh terhadap keluarga dalam memenuhi segala kebutuhan rumah tangga serta menyekolahkan anak-anak mereka. Wanita pun dalam keluarga tidak dapat diabaikan begitu saja dalam menentukan roda kehidupan keluarga. Sebagai contoh istri nelayan, setelah suami atau kaum laki-laki pulang dari laut mencari nafkah, selanjutnya diambil alih oleh kaum wanita di mana semua hasil yang diperoleh kaum laki-laki (suami) tadi mereka olah dan dikerjakan hinga pada tahap pemasaran. Akibat dari kerjasama yang terjalin dengan baik pada sebuah keluarga ini sehingga berpengaruh pula pada kualitas ke hidupan mereka di antaranya di bidang pendidikan dengan menyekolahkan anak mereka bahkan hingga ke perguruan tinggi.

\section{Kondisi Budaya}

Budaya merupakan faktor pendukung pembentukan suatu desa. Melalui kegiatan pembangunan dalam bidang sosial budaya diharapkan antara masyarakat yang ada di Desa Polewali baik yang beragam suku yang ada didalamnya maupun pemerintah terjalin hubungan yang harmonis, hormat menghormati, guna dalam menciptakan susana yang harmonis dan kondusif sehingga dapat meningkatkan taraf hidup dan kesejahtraan masyarakat yang ada di Desa Polewali. Budaya merupakan salah satu bagian terpenting dalam kehidupan masyarakat nelayan yang digunakan sebagai tata aturan yang mengatur pola perilaku setiap anggota-anggota dalam kehidupan masyarakat Desa Polewali aturan-aturan tersebut dikenai dengan istilah pamali yang merupakan peraturan tidak tertulis yang harus dipatuhi oleh seluruh masyarakat nelayan berdasarkan suatu konsensus yang dibuat aturan ini dijadikan sebagai pedoman dalam kehidupan masyarakat contohnya dalam penentuan keputusan, ketetapan syarat menjadi keputusan tertinggi. Aturan ini berkembang hingga saat ini dan masih tetap digunakan dalam kehidupan masyarakat nelayan 
Masyarakat nelayan di Desa Polewali setiap tahun selalu mengadakan acara mandre andre (makan-makan) untuk mensyukuri rejeki yang mereka diberikan. Acara mandre andre (makamakan ) ini biasanya diadakan di sekitaran laut Polewali ini sudah menjadi tradisi bagi masyarakat nelayan Desa Polewali. Di samping sebagai salah satu bentuk mensyukuri pemberian yang maha kuasa mandre andre (makan-makan) juga sebagai salah satu wadah silaturahim bagi para masyarakat nelayan.

\section{KESIMPULAN}

Berdasarkan hasil penelitian dapat disimpulkan bahwa pertama awal kedatangan orang Bugis di Desa Polewali untuk mengamankan diri karena pada saat itu mereka dikira mata-mata dari tentara Jepang jadi mereka meninggalkan daerah asal mereka yaitu Bone Sulawesi Selatan dan kemudian mereka menuju di Desa Polewali. Desa Polewali merupakan Desa yang berada di pesisir laut daratan Sulawesi Tenggara. Nama Desa Polewali berasal dari bahasa Bugis yaitu kata Pole dan Wali. Pole artinya datang dari dan Wali yang artinya empat penjuru. Polewali berarti datang dari empat penjuru, karena pada saat itu di Desa Polewali banyak terdapat mata air untuk kebutuhan manusia. Desa Polewali terbentuk pada tahun 1955 sebelum terbentuk sebagai desa. Pada tahun 1950 Orang Bugis pertama sekali berlayar di Desa Polewali hanyalah sebuah tempat persinggahan Orang-orang Bugis yang berlayar dari Bone Sulawesi Selatan ke Kendari Sulawesi Tenggara karena kondisi alam yang mendukung akhirnya sebagian orang memilih untuk menetap dan bermukim diwilayah ini. Masyarakat suku Bugis di Desa Polewali berasal dari beberapa wilayah di Sulawesi Selatan yaitu ada yang berasal dari Bone, Sinjai, Sengkang dan beberapa wilayah lain sekitarnya. Kedua kondisi sosial, ekonomi, dan budaya nelayan Suku Bugis pada awal kedatangan (1950-1980) masih menggunakan sistem barter, alat yang digunakan untuk menangkap ikan masih sederhana berupa pancing dan jaring, perahu yang digunakan untuk menangkap ikan belum menggunakan mesin. Perkembangan perekonomian pada tahun 1980-2000: telah mengenal sistem perdagangan, perahu yang digunakan telah menggunakan mesin, telah dibangun pelelangan ikan kecil-kecilan sebagai sarana penjualan hasil laut. Perkembangan perekonomian saat ini (20002017) meliputi penangkapan ikan memiliki kemajuan yaitu membuat beberapa keramba dan menggunakan mesin tees, beberapa masyarakat Bugis berprofesi ganda yaitu sebagai pedagang dan nelayan, taraf hidup meningkat sehingga berdampak pada pendidikan dan politik. Perkembangan sosial budaya masyarakat nelayan di Desa Polewali banyak terlihat lewat budaya pamali yang banyak diterapkan, misalnya ketika nelayan hendak keluar mencari ikan tidak boleh bersin, duduk di depan pintu, seseorang tidak boleh bertanya mau ke mana dan tidak boleh mengeluarkan makanan di luar rumah karna akan memepengaruhi pada pendapatan nelayan. Masyarakat nelayan di Desa Polewali setiap tahun selalu mengadakan acara mandre andre (makan-makan) untuk mensyukuri rejeki yang mereka di berikan. Acara mandre andre (makanmakan ) ini biasanya di adakan di sekitaran laut Polewali ini sudah menjadi tradisi bagi masyarakat nelayan Desa Polewali. Di samping sebagai salah satu bentuk mensyukuri pemberian yang maha kuasa mandre andre (makan-makan) juga sebagai salah satu wadah silaturahim bagi para masyarakat nelayan.

\section{DAFTAR PUSTAKA}

Hassan Shaddily. 1993. Sosiologi untuk Masyarakat Indonesia. Jakarta: Rineka Cipta.

Helius Syamsudin. 2007. Metodologi Seajarah. Yogyakarta : Ombak

Muhammad Arief. 2011. Pengantar Kajian Ilmu Sejarah. Bandung. Y ramah Widya

Mulyadi. 2005. Peranan Masyarakat Nelayan Pesisir. Jakarta : Bharata Aksara

Nasution. 1998. Komunikasi Pembangunan Pengenalan Teori dan Penerapannya. Jakarta: Raja Grafindo Persada

Sartono Kartodirdjo, 2002. Teori Sejarah dan Masalah Histografi. Jakarta: Gramedia.

Sartono Kartodirjo, et. al. 1990. Sejarah Pergerakan Nasional Dari Kolonialisme Sampai Nasionalisme. Jakarta: Gramedia.

Satria. 2002. Masyarakat Nelayan. Harian Pagi Sriwijaya Post. Palembang 21 Mei, 2002. 